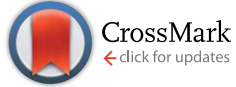

Cite this: J. Mater. Chem. A, 2014, 2 , 20861

Received 5th June 2014

Accepted 21st September 2014

DOI: $10.1039 / c 4 t a 02840 f$

www.rsc.org/MaterialsA

\title{
Development of new anode composite materials for fluoride ion batteries $\uparrow$
}

\begin{abstract}
C. Rongeat, ${ }^{a}$ M. Anji Reddy, ${ }^{\text {ab }}$ T. Diemant, ${ }^{c}$ R. J. Behm ${ }^{\text {bc }}$ and M. Fichtner ${ }^{\star a b}$
Due to their high theoretical energy density values, Fluoride lon Batteries (FIB) are interesting alternatives to $\mathrm{Li}$-ion batteries. Recently, results have been reported on the reversible charge and discharge of such systems using a solid electrolyte, various metal fluorides as cathode materials and Ce metal as the anode. The work in the present study is focused on the development of new anode materials which do not contain Li. To facilitate cell preparation and material handling, cells were prepared in the discharged state with $\mathrm{Bi}$ or $\mathrm{Cu}$ as the cathode material and $\mathrm{CeF}_{3}, \mathrm{CaF}_{2}$ or $\mathrm{MgF}_{2}$ as potential anode materials. The charge and discharge mechanisms were examined by detailed ex situ X-ray diffraction (XRD) and X-ray photoelectron spectroscopy (XPS) experiments. The best cycling performances were obtained with $\mathrm{MgF}_{2}$ but prepared in the half-discharged state (i.e. mixed with $\mathrm{Mg}$ ), thus forming a composite that could provide better interface contacts between the different reactive phases. The results showed that apart from choosing carefully the electrode active materials, it is also important to optimise the architecture of the electrodes.
\end{abstract}

\section{Introduction}

The increasing demand for high energy storage systems has prompted the interest in alternative chemistry for new battery systems, ${ }^{1-5}$ with better performances than the currently used Liion batteries. Recently, the reversible charge and discharge of batteries based on a fluoride shuttle has been demonstrated for a relatively moderate temperature and with reasonable performances. ${ }^{6}$ Such a Fluoride Ion Battery (FIB) has a high theoretical energy density, of up to more than $5000 \mathrm{~W} \mathrm{~h} \mathrm{~L}^{-1}$ for some electrode combinations. This type of battery is still at an early stage of development and large improvements are needed concerning the performance of the electrodes, as well as of the electrolyte. The capacities do not reach the maximum theoretical values and fade quickly during cycling. In the first study by Anji Reddy and Fichtner, ${ }^{6}$ the electrodes were composite materials where the active materials were mixed with carbon for good electronic conductivity and in some cases with the

${ }^{a}$ Karlsruhe Institute of Technology (KIT), Institute of Nanotechnology, Hermann-von-Helmholtz-Platz 1, D-76344 Eggenstein-Leopoldshafen, Germany. E-mail:m.fichtner@kit.edu

${ }^{b}$ Helmholtz Institute Ulm (HIU) for Electrochemical Energy Storage, Albert-EinsteinAllee 11, D-89081 Ulm, Germany

${ }^{c}$ Ulm University, Institute of Surface Chemistry and Catalysis, Albert-Einstein-Allee 47, D-89081 Ulm, Germany

$\dagger$ Electronic supplementary information (ESI) available: A table giving the most relevant theoretical properties of the electrode active materials. A scanning electron micrograph of the pellet used for electrochemical measurements, the XRD patterns of the starting $\mathrm{Bi}$ and $\mathrm{Cu}$ powders and the voltage profiles of the first charging obtained for the various anode materials with different cut-off potentials. See DOI: 10.1039/c4ta02840f electrolyte to ensure a good ionic conductivity. Such cells were made using solid electrolytes composed of doped fluoride salts implying the need for operating the cells at elevated temperatures. Alkaline-earth fluorides having a fluorite-type structure $\left(\mathrm{BaF}_{2}, \mathrm{SrF}_{2}\right.$ or $\left.\mathrm{CaF}_{2}\right)$ or rare-earth fluorides having a tysonitetype structure $\left(\mathrm{LaF}_{3}, \mathrm{CeF}_{3}\right)$ are potential candidates for electrolytes. Previous studies have shown that it is possible to improve the ionic conductivity of doped- $\mathrm{BaF}_{2}$ by preparing a nanostructured material using ball milling. ${ }^{7-11}$ Higher conductivity values were also achieved using $\mathrm{LaF}_{3}$-based compounds, especially after heat treatment performed to obtain the appropriate microstructure. ${ }^{12}$ For this last type of material, the formation of a nanostructured compound did not appear to provide any advantage to the ionic conductivity. Recently, the first example of a liquid electrolyte for $\mathrm{F}$ anion conduction has also been developed. ${ }^{13}$ Although further improvements are necessary in this direction, the development of liquid electrolytes opens new possibilities to operate a FIB at room temperature and increase the interest for developing new electrode materials as well.

A few earlier examples of FIBs have already been reported in the literature mostly for primary cells (only discharge). For example, using a thin film geometry, Kennedy and Hunter ${ }^{14}$ prepared a primary cell using $\mathrm{Pb}$ as the anode, $\mathrm{PbF}_{2}$ as the electrolyte and $\mathrm{CuF}_{2}$ as the cathode (mixed with $\mathrm{PbF}_{2}$ to ensure good ionic conductivity). They were able to discharge this cell at room temperature to a maximum of $40 \%$ of the theoretical capacity. However, the voltage was rather low $(0.4-0.5 \mathrm{~V})$. Similar results have been reported for a cell with $\mathrm{BiO}_{0.09} \mathrm{~F}_{2.82}$ as the cathode instead of $\mathrm{CuF}_{2} \cdot{ }^{15}$ Other studies have shown that better discharge performances could be obtained using a 
doped-Ca anode $\mathrm{P}^{\mathbf{1 6 , 1 7}}$ instead of the pure $\mathrm{Ca}$ anode and that a voltage of $c a .3 \mathrm{~V}$ could be reached with $\mathrm{BiO}_{0.1} \mathrm{~F}_{2.8}$ as the cathode. Higher capacities have been reported by Potanin ${ }^{\mathbf{1 8}}$ using $\mathrm{La}$ or $\mathrm{Ce}$ as the anode, doped $\mathrm{LaF}_{3}$ or $\mathrm{CeF}_{3}$ as the electrolyte and doped $\mathrm{PbF}_{2}$ or $\mathrm{BiF}_{3}$ as the cathode. The first discharge delivered ca. $130 \mathrm{~mA} \mathrm{~h} \mathrm{~g}^{-1}\left(\mathrm{PbF}_{2}\right)$ or ca. $200 \mathrm{~mA} \mathrm{~h} \mathrm{~g}^{-1}$ $\left(\mathrm{BiF}_{3}\right)$ at around $2-2.5 \mathrm{~V}$ but using rather high temperatures $(500$ ${ }^{\circ} \mathrm{C}$ ). To the best of our knowledge, only a few examples of rechargeable FIBs have been described. For instance, Danto et al. ${ }^{19}$ prepared such a cell from submicron films of $\mathrm{Bi}$ and $\mathrm{PbF}_{2}$ that were deposited on top of each other and first charged to obtain the desired structure $\mathrm{Pb} / \mathrm{PbF}_{2} / \mathrm{BiF}_{3} / \mathrm{Bi}$. It was possible to perform a few cycles of discharge and charge (with $\mathrm{Pb}$ as the anode, $\mathrm{PbF}_{2}$ as the electrolyte and $\mathrm{BiF}_{3}$ as the cathode) but with low capacities and at a voltage of $250-300 \mathrm{mV}$ with a current density of $40 \mu \mathrm{A} \mathrm{cm} \mathrm{cm}^{-2}$.

In the recent study mentioned above, ${ }^{6}$ different types of metal fluorides were tested as cathodes: $\mathrm{BiF}_{3}, \mathrm{CuF}_{2}, \mathrm{SnF}_{2}$ or $\mathrm{KBiF}_{4}$ and $\mathrm{Ce}$ metal was used as the anode. Especially with $\mathrm{BiF}_{3}$ as the cathode, it was possible to obtain dozens of charge/ discharge cycles. However, Ce metal, as well as other potential anode materials like $\mathrm{La}, \mathrm{Ca}, \mathrm{Li}$ or $\mathrm{Mg}$, are sensitive to surface oxidation, even when stored in an Ar filled glove box. This may lead to rapid degradation of the performance of these materials when used as anodes. In the present study, we therefore decided to prepare electrode materials in the discharged state to investigate new anode materials, using mostly Bi metal as a precursor for the cathode. We prepared several composite materials and analysed their cycling performances. Different characterization techniques were used to understand the different reactions taking place in the electrodes during charge and discharge.

\section{Experimental}

\section{Materials preparation}

All material handling was performed in an inert atmosphere in an Ar filled glove box with recirculation. $\mathrm{LaF}_{3}$ (anhydrous, 99.9\% (REO)), $\mathrm{CeF}_{3}$ (anhydrous, 99.9\% (REO)), $\mathrm{BaF}_{2}$ (99.9\%), $\mathrm{CaF}_{2}$ (99.7\%) and $\mathrm{Mg}$ (99.6\%) were obtained from Alfa Aesar. $\mathrm{MgF}_{2}$ (99.9\%) and $\mathrm{Bi}$ (99\%) were obtained from Sigma Aldrich and $\mathrm{Cu}$ nanoparticles (99.9\%) were obtained from Sky Spring Nanomaterials, Inc. Cathode, anode and electrolyte materials were prepared by ball milling under an Ar atmosphere at $600 \mathrm{rpm}$ in a $\mathrm{Si}_{3} \mathrm{~N}_{4}$ vial (ball-to-powder ratio $12: 1$ ) using a planetary-type mill (Fritsch Pulverisette 6). The starting powders were dried at appropriate temperatures (typically $250{ }^{\circ} \mathrm{C}$ ) in a vacuum for several hours prior to milling. The tysonite-type $\mathrm{La}_{0.9} \mathrm{Ba}_{0.1} \mathrm{~F}_{2.9}$ electrolyte was prepared by ball milling of a mixture of $\mathrm{LaF}_{3}$ and $\mathrm{BaF}_{2}$ for $12 \mathrm{~h} .{ }^{12}$ The cathode material was a composite of $\mathrm{Bi}$ or $\mathrm{Cu}(30 \mathrm{wt} \%)$ mixed with $\mathrm{La}_{0.9} \mathrm{Ba}_{0.1} \mathrm{~F}_{2.9}(60 \mathrm{wt} \%)$ and $\mathrm{C}(10 \mathrm{wt} \%)$ to ensure both ionic and electronic conductivity. Different anode composites were tested based on $\mathrm{CeF}_{3}, \mathrm{CaF}_{2}$ and $\mathrm{MgF}_{2}$ compounds. For the preparation of electrode composites containing the electrolyte, an appropriate amount of the $\mathrm{BaF}_{2}+$ $\mathrm{LaF}_{3}$ mixture was ball milled for $4 \mathrm{~h}$ and then addition of $\mathrm{Bi}$ or $\mathrm{Cu}$ or $\mathrm{MgF}_{2}$ and $\mathrm{C}$ and milling for another $12 \mathrm{~h}$ were performed. The compositions and the preparation of the different anode composites are given in Table $1 . \mathrm{CeF}_{3}$ - and $\mathrm{CaF}_{2}$-based anode materials can be used without adding a fraction of the electrolyte as both compounds are ionic conductors for fluoride anions. Table S1 (see †) summarises some relevant theoretical properties for the different electrode active materials.

\section{Cell preparation}

Test cells were prepared by pressing together three-layered pellets ( $7 \mathrm{~mm}$ diameter) of anode/electrolyte/cathode materials. The three layers were pressed for $c a .1 \mathrm{~min}$ using a desktop press (International Crystal Laboratory). The thickness of each layer was approximately $300 \mu \mathrm{m}, 750 \mu \mathrm{m}$ and $100 \mu \mathrm{m}$ for the anode, electrolyte and cathode layer, respectively. A scanning electron micrograph of the pellet cross-section is shown in the ESI (Fig. S1 $\dagger$ ). The pellets were then spring-loaded in a modified Swagelok-type cell using stainless steel current collectors.

\section{Electrochemical testing}

For cycling experiments, the cells were heated to $c a .150{ }^{\circ} \mathrm{C}$ using band heaters. The charge and discharge steps were performed using an Arbin BT 2000 (16 channels) battery tester. The current density applied was ca. $4 \mathrm{~mA} \mathrm{~g}^{-1}\left(10 \mu \mathrm{A} \mathrm{cm}^{-2}\right)$ for all tests. The capacities were calculated referring to the weight of the active material in the cathode ( $\mathrm{Bi}$ or $\mathrm{Cu}$ only), as anode active materials were used in excess.

Table 1 Anode composites and preparation conditions (anode short names will be used in the discussion)

\begin{tabular}{|c|c|c|c|}
\hline Anode short name & Composition & Milling duration & Remarks \\
\hline $\mathrm{CeF}_{3}$ & $\begin{array}{l}90 \mathrm{wt} \% \mathrm{CeF}_{3} \\
10 \mathrm{wt} \% \mathrm{C} \text { black }\end{array}$ & $12 \mathrm{~h}$ & As-received $\mathrm{CeF}_{3}$ \\
\hline $\mathrm{CaF}_{2}$ & $\begin{array}{l}90 \text { wt } \% \mathrm{Ca}_{0.6} \mathrm{La}_{0.4} \mathrm{~F}_{2.4} \\
10 \mathrm{wt} \% \mathrm{C} \mathrm{black}\end{array}$ & $12 \mathrm{~h}$ & $\mathrm{Ca}_{0.6} \mathrm{La}_{0.4} \mathrm{~F}_{2.4}$ prepared by milling $\mathrm{CaF}_{2}$ and $\mathrm{LaF}_{3}$ for $48 \mathrm{~h}$ before \\
\hline $\mathrm{MgF}_{2}$ & $\begin{array}{l}30 \mathrm{wt} \% \mathrm{MgF}_{2} \\
60 \mathrm{wt} \% \mathrm{La}_{0.9} \mathrm{Ba}_{0.1} \mathrm{~F}_{2.9} \\
10 \mathrm{wt} \% \mathrm{C} \mathrm{black}\end{array}$ & $12 \mathrm{~h}$ & $\mathrm{La}_{0.9} \mathrm{Ba}_{0.1} \mathrm{~F}_{2.9}$ prepared by milling $\mathrm{LaF}_{3}$ and $\mathrm{BaF}_{2}$ for $4 \mathrm{~h}$ before \\
\hline $\mathrm{Mg}+\mathrm{MgF}_{2}$ & $\begin{array}{l}20 \mathrm{wt} \% \mathrm{Mg} \\
20 \mathrm{wt} \% \mathrm{MgF}_{2} \\
50 \mathrm{wt} \% \mathrm{La}_{0.9} \mathrm{Ba}_{0.1} \mathrm{~F}_{2.9} \\
10 \mathrm{wt} \% \mathrm{C} \mathrm{black}\end{array}$ & $12 \mathrm{~h}$ & $\mathrm{La}_{0.9} \mathrm{Ba}_{0.1} \mathrm{~F}_{2.9}$ prepared by milling $\mathrm{LaF}_{3}$ and $\mathrm{BaF}_{2}$ for $4 \mathrm{~h}$ before \\
\hline
\end{tabular}




\section{X-ray diffraction (XRD)}

XRD measurements were performed using a Bruker D8 Advance instrument with $\mathrm{Cu} \mathrm{K} \alpha$ radiation. Rietveld refinement was performed using MAUD software (Materials Analysis Using Diffraction) developed by L. Lutterotti. ${ }^{20}$ XRD patterns were measured directly at the back of the cathode side of the pellets used for electrochemical testing.

\section{X-ray photoelectron spectroscopy (XPS)}

For the XPS measurements, a PHI 5800 MultiTechnique ESCA System (Physical Electronics) was employed. The spectra were acquired using monochromatic $\mathrm{Al} \mathrm{K} \alpha(1486.6 \mathrm{eV})$ radiation with a detection angle of $45^{\circ}$, using pass energies at the analyzer of 93.9 and $29.35 \mathrm{eV}$ for survey and detail spectra, respectively. Charging of the samples was neutralised with electrons from a flood gun (current $3 \mu \mathrm{A}$ ). The binding energy of the XPS peaks was referenced to the $\mathrm{C}(1 \mathrm{~s})$ signal of adventitious carbon at $284.8 \mathrm{eV}$.

\section{Results and discussion}

\section{Fully discharged $\mathrm{CeF}_{3}$ anode vs. a Bi cathode}

$\mathrm{CeF}_{3}$ was first tested as an anode material using metallic Bi as the cathode and $\mathrm{La}_{0.9} \mathrm{Ba}_{0.1} \mathrm{~F}_{2.9}$ as the electrolyte. Bi was chosen because of the good cycling properties obtained when studying the cycling behaviour of $\mathrm{a} \mathrm{BiF}_{3}$ cathode against a Ce metal anode. ${ }^{6}$ The cells were prepared as three-layered pellets and the charge and discharge cycles were performed at $150{ }^{\circ} \mathrm{C}$ to ensure sufficient ionic conductivity in the solid electrolyte. Fig. 1a shows the evolution of the voltage during the first charge obtained with a cut-off potential of $4 \mathrm{~V}$. The open circuit voltage (OCV) values measured before charging were very low ( 0.1 to 0.4 V) and the voltage values increased slowly when applying the charge current. The charge process seemed to be composed of three steps with first a slow increase of the voltage up to $2.4 \mathrm{~V}$, then a rather flat plateau up to $c a .3 \mathrm{~V}$, and finally another slow increase of the voltage from $c a$. 3.1 to $4 \mathrm{~V}$. The capacity obtained for the first charge to $4 \mathrm{~V}$ was $404 \mathrm{~mA} \mathrm{~h} \mathrm{~g}^{-1}$ (referred to the active material in the cathode) which is higher than the theoretical capacity of the $\mathrm{Bi} / \mathrm{BiF}_{3}$ cathode $\left(385 \mathrm{~mA} \mathrm{~h} \mathrm{~g}^{-1}\right.$ when referring to the mass of $\mathrm{Bi}$ only), indicating that side reaction(s) occurred during the first charge.

To identify the processes in the different steps described above, charging was stopped at different voltages as indicated in Fig. 1a and the respective pellets were analysed by XRD. The resulting XRD patterns are given in Fig. 1b. After the cathode composite preparation by ball milling (before charging), two phases were observed: the electrolyte $\mathrm{La}_{0.9} \mathrm{Ba}_{0.1} \mathrm{~F}_{2.9}$ and the active material $\mathrm{Bi}$. Both phases displayed broad diffraction peaks in agreement with the small crystallite sizes (16 $\mathrm{nm}$ for $\mathrm{La}_{0.9} \mathrm{Ba}_{0.1} \mathrm{~F}_{2.9}$ and $37 \mathrm{~nm}$ for $\mathrm{Bi}$ ) that are usually obtained after ball milling. After charging to $2 \mathrm{~V}$, new peaks appeared which are attributed to $\beta-\mathrm{BiF}_{3-2 x} \mathrm{O}_{x}$ with a cubic (fluorite) structure $(0.41 \leq x \leq 0.52) .{ }^{21}$ This phase is assumed to result from the fluorination of the $\mathrm{Bi}_{2} \mathrm{O}_{3}$ phase present in the starting $\mathrm{Bi}$ powder (approx. 19 wt\% detected by XRD, see ESI Fig. S2 $\dagger$ ). The cell
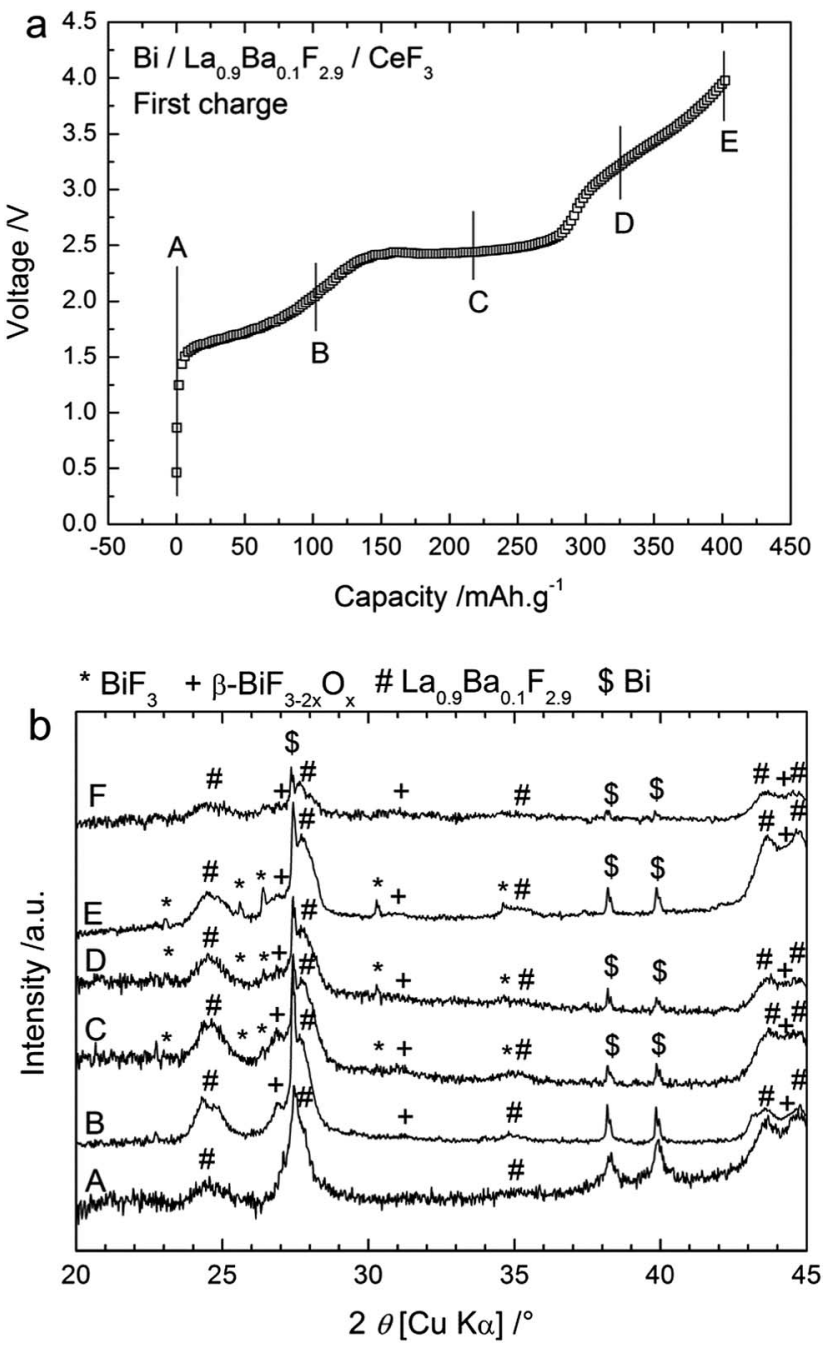

Fig. 1 (a) First charging curve obtained for a cell composed of a $\mathrm{Bi}$ cathode and $\mathrm{CeF}_{3}$ as the anode. The charging curve was obtained at $150{ }^{\circ} \mathrm{C}$ for a current density of ca. $4 \mathrm{~mA} \mathrm{~g}^{-1}$ and (b) XRD patterns measured after charging to different voltages: (A) before charging and after charging to (B) $2 \mathrm{~V}$, (C) $2.5 \mathrm{~V}$, (D) $3.2 \mathrm{~V}$, (E) $4 \mathrm{~V}$ as indicated in the voltage profile and (F) after 1 cycle (charge + discharge).

parameter of the oxyfluoride determined by Rietveld refinement was $5.78 \AA$, which is smaller than the value of $5.85 \AA$ reported for $x=0.51$. Note that the high-temperature phase of $\mathrm{Bi}_{2} \mathrm{O}_{3}(x=3$ / 2) existing above $730{ }^{\circ} \mathrm{C}$ also shows a fluorite-type structure with a lattice parameter of $5.66 \AA$. Hence, assuming a decrease of the cell parameter with increasing $\mathrm{O}$ content, a higher quantity of oxygen than $x=0.51$ is expected in the cathode material. After charging to $2.5 \mathrm{~V}$, peaks corresponding to $\mathrm{BiF}_{3}$ were detected in addition to this $\beta-\mathrm{BiF}_{3-2 x} \mathrm{O}_{x}$ phase. The cell parameter for $\beta$ $\mathrm{BiF}_{3-2 x} \mathrm{O}_{x}$ was $5.81 \AA$ in that case, indicating a higher quantity of fluorine in this phase. The two phases $\mathrm{BiF}_{3}$ and $\beta-\mathrm{BiF}_{3-2 x} \mathrm{O}_{x}$ were also observed after charging to $3.2 \mathrm{~V}$ but with somewhat higher intensities. In contrast, after charging to $4 \mathrm{~V}$, no new phase appeared in the XRD pattern so that the charging step from 3.2 to $4 \mathrm{~V}$ likely corresponds to the formation of $\mathrm{BiF}_{5}$ from the $\mathrm{BiF}_{3}$ phase previously formed during the second step. The formation of $\mathrm{BiF}_{5}$ could explain the high capacity obtained 
during first charging. The structure reported for $\mathrm{BiF}_{5}$ (orthorhombic $I 4 / \mathrm{m}$ ) gives diffraction peaks that are overlapping with those of $\mathrm{BiF}_{3}$ and this phase may be unstable explaining why we could not observe it by XRD.

Note that for all XRD patterns, the presence of unreacted $\mathrm{Bi}$ was detected although the capacity measured suggested a complete charge reaction (the measured value was above the theoretical capacity). It likely corresponds to bulk Bi inside the particles that could not be reached and converted during charging. This assumption is in agreement with the capacity value measured after the second step (slightly below $300 \mathrm{~mA} \mathrm{~h}$ $\mathrm{g}^{-1}$ ), which corresponds to an incomplete conversion of Bi into $\mathrm{BiF}_{3}$ and with the formation of the $\mathrm{BiF}_{5}$ in the third step from $\mathrm{BiF}_{3}$ obtained during the second step. It is difficult to evaluate the relative content of each phase from the XRD measurements because of the low intensity of the diffraction peaks. Nevertheless, Rietveld refinement of the XRD patterns tended to indicate that the relative quantity of $\mathrm{BiF}_{3}$ increased after charging to 3.2 $\mathrm{V}$ compared to after charging to $2.5 \mathrm{~V}$.

These results suggest the following three-step reaction path during charging to $4 \mathrm{~V}$. The first charging step (below ca. $2.4 \mathrm{~V}$ ) leads to the formation of $\beta-\mathrm{BiF}_{3-2 x} \mathrm{O}_{x}$, likely from the fluorination of the $\mathrm{Bi}_{2} \mathrm{O}_{3}$ phase present in the starting $\mathrm{Bi}$ powder. Generally, the fluorination of oxides is expected to occur at a higher voltage than the fluorination of metals because of the higher oxidation states involved. However, in the present case, the oxidation state is not changed due to a substitutional fluorination ( $\mathrm{O}$ atoms are replaced by $\mathrm{F}$ atoms), Bi remains in the $3+$ oxidation degree so it is possible that the fluorination of $\mathrm{Bi}_{2} \mathrm{O}_{3}$ occurs at a lower voltage than that of $\mathrm{Bi}$. Nevertheless, some electrons are exchanged during this reaction although the oxidation state of $\mathrm{Bi}$ remains constant as the fluorination process involves the reaction of $\mathrm{Bi}_{2} \mathrm{O}_{3}$ with $\mathrm{F}$ anions. Unfortunately, thermodynamic data are missing for the compound $\beta-\mathrm{BiF}_{3-2 x} \mathrm{O}_{x}$ and we could not calculate the electromotive force (emf) for this step. The second step (plateau at 2.5-2.7 V) is the formation of $\mathrm{BiF}_{3}$ from $\mathrm{Bi}$; the plateau voltage is in agreement with the theoretical electromotive force of the $\mathrm{Bi} / \mathrm{BiF}_{3}$ redox couple $v s$. $\mathrm{Ce} / \mathrm{CeF}_{3}(2.66 \mathrm{~V})$. The third step $(>3.2 \mathrm{~V})$ may correspond to the formation of $\mathrm{BiF}_{5}$ from freshly converted $\mathrm{BiF}_{3}$.

XPS measurements on the back sides of the cathodes confirmed the formation of new fluoride compounds in the cathode after charging the pellets to different voltages (Fig. 2). The spectra measured for the Bi $4 \mathrm{f}$ binding energy region for the (untreated) surface and after short sputtering of the outer layer are shown in Fig. 2a and 2 b. After the cell preparation (for the as-milled cathode material), the surface of the cathode was composed of two Bi compounds reflected by two doublet peaks for the $\mathrm{Bi} 4 \mathrm{f} 7 / 2$ and $\mathrm{Bi} 4 \mathrm{f} 5 / 2$ states. The doublet at $157.5 \mathrm{eV}$ and $162.8 \mathrm{eV}$ binding energies and with the lower intensity can be ascribed to metallic $\mathrm{Bi}$; the doublet at $159.4 \mathrm{eV}$ and $164.7 \mathrm{eV}$ likely corresponds to $\mathrm{Bi}_{2} \mathrm{O}_{3} \cdot{ }^{22}$ After sputtering of the outer surface, the peak positions remained similar for the two doublets but the intensity ratio was opposite, pointing to an oxide enrichment of the surface, which was reduced by sputtering.
After charging to $2.5 \mathrm{~V}$, the XP spectra still showed two doublets. The first one corresponding to metallic Bi (157.5 and $162.8 \mathrm{eV}$ ) was still at the same position, while the second one shifted to slightly higher binding energies, to 159.7 and $165.0 \mathrm{eV}$ (159.9 and $165.2 \mathrm{eV}$ after sputtering). After charging to $3.2 \mathrm{~V}$, the first peak doublet related to metallic $\mathrm{Bi}$ was not detected anymore, while the second one continued to shift to higher binding energies (159.7 and $165.0 \mathrm{eV}$ ). The shift of the second component to higher binding energy confirms the formation of fluorinated Bi compounds as the binding energy values of these peaks are in good agreement with a spectrum measured for pure $\mathrm{BiF}_{3}$ (Fig. 2a and b) and with the values given by Morgan et $a .^{22}$ Interestingly, upon charging, the charge reaction occurred through the complete cathode composite and not only at the cathode/electrolyte interface, as it can be detected on the outer surface. Unfortunately, we could not distinguish between the $\mathrm{BiF}_{3}$ and $\beta-\mathrm{BiF}_{3-2 x} \mathrm{O}_{x}$ phases by XPS, as their binding energies are similar. ${ }^{23}$ However, the presence of these two compounds may explain the slight shifts in binding energies observed after charging (to 2.5 or $3.2 \mathrm{~V}$ ) and after subsequent sputtering at the surface. The presence of the oxyfluoride phase can be assumed at the surface where a significant amount of $\mathrm{Bi}_{2} \mathrm{O}_{3}$ was detected before charging, but not afterwards.

XP spectra of the F 1s (Fig. 2c) and La 3d (Fig. 2d) regions were also measured for additional information. The F 1 s spectrum displayed one main peak at $685.4 \mathrm{eV}$ after milling, which results from the $\mathrm{LaF}_{3}$-based electrolyte present in the composite. After charging, the binding energy of this peak decreased to $684.6 \mathrm{eV}$. This peak position agrees well with the binding energy measured for the $\mathrm{F} 1 \mathrm{~s}$ peak of a $\mathrm{BiF}_{3}$ reference (see Fig. 2c). Therefore, this shift could also indicate the formation of $\mathrm{BiF}_{3}$. The $\mathrm{La} 3 \mathrm{~d}$ spectrum remained essentially unchanged before and after charging, indicating that the electrolyte added to the cathode composite did not react when charged to $3.2 \mathrm{~V}$. The peak energies for the as-prepared cathode at 841.9, 837.4 and 830.2 eV for the La 3d5/2 level and 858.7 and $854.2 \mathrm{eV}$ for the La $3 \mathrm{~d} 3 / 2$ level, as well as the spectrum shape are in agreement with the spectrum measured for a pure $\mathrm{LaF}_{3}$ compound (see Fig. 2d). ${ }^{\mathbf{2 4}, 25}$ The binding energy values are slightly higher than for the pure $\mathrm{LaF}_{3}$ material, but we assume that slight shifts in the peak energies can occur for the composite material due to the $\mathrm{BaF}_{2}$ doping of the material. In addition, the peak shape is quite different from the spectra measured for $\mathrm{LaOF}^{24}$ or $\mathrm{La}_{2} \mathrm{O}_{3}$ (ref. 26) compounds excluding any major oxygen contamination in our samples.

The cycling behaviour of a $\mathrm{Bi} / \mathrm{La}_{0.9} \mathrm{Ba}_{0.1} \mathrm{~F}_{2.9} / \mathrm{CeF}_{3}$ cell in the first cycles is depicted in Fig. 3 using different charge cut-off potentials, i.e. for different conversion states of Bi. In each case, the capacity during the first discharge was very low with a maximum of $20 \mathrm{~mA} \mathrm{~h} \mathrm{~g}{ }^{-1}$ when using a 3.2 or $4 \mathrm{~V}$ cut-off potential during the first charge while only half of this value was obtained using a $3.5 \mathrm{~V}$ cut-off potential. The origin of this difference has been unclear so far, although this observation was reproducible. After stopping the charging at 3.2 or $3.5 \mathrm{~V}$, the discharge voltage profile was composed of a single plateau at $c a$. $2 \mathrm{~V}$ when charging took place up to $3.2 \mathrm{~V}$, and $c a$. $1.6 \mathrm{~V}$ after charging up to $3.5 \mathrm{~V}$. In both cases, the following charge was 

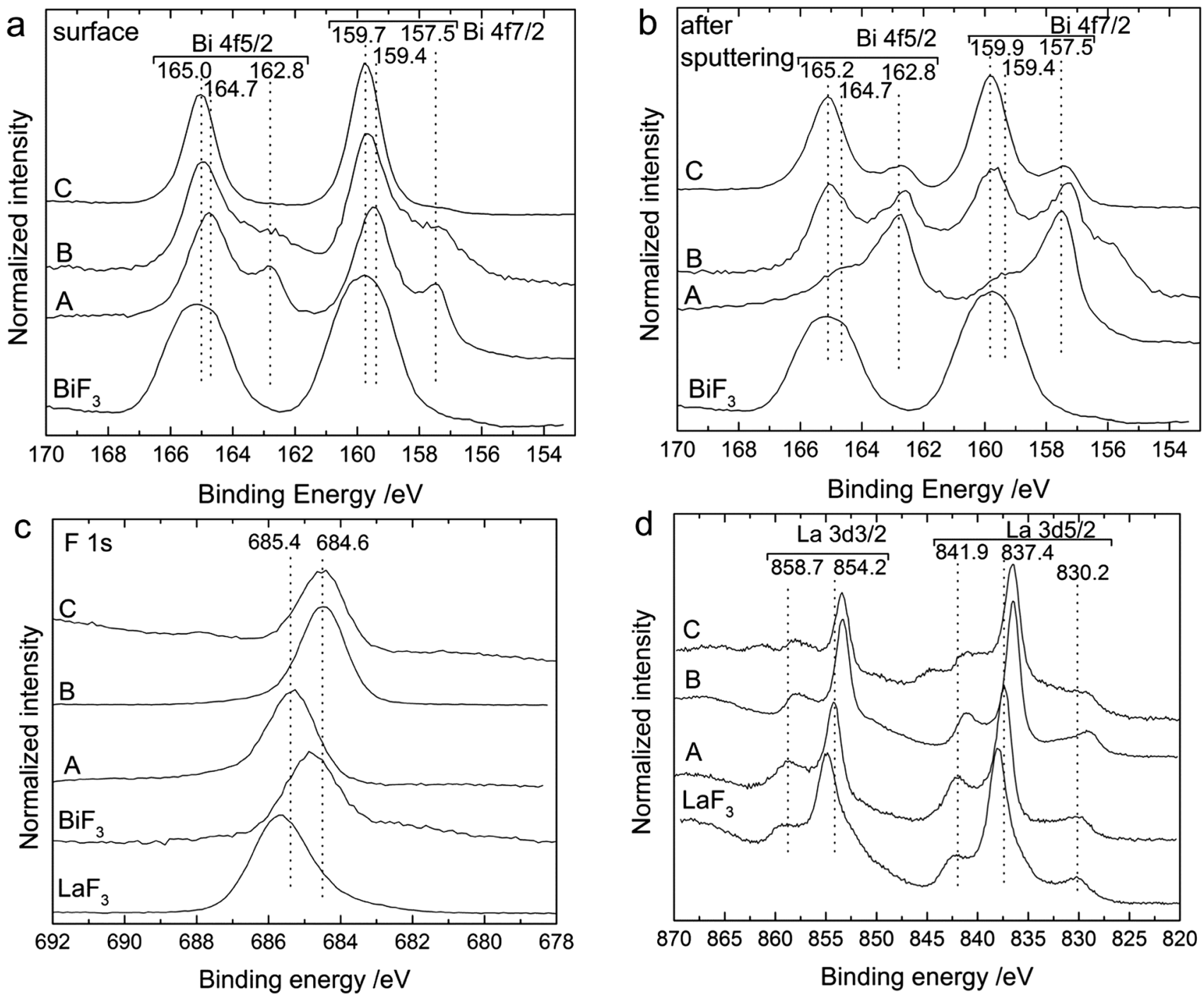

Fig. 2 XP spectra for the Bi $4 f$ region measured (a) at the surface and (b) after sputtering the outer layer, (c) for the F 1s (surface) and (d) for the La $3 \mathrm{~d}$ (surface) regions of the back side of the cathode for $\mathrm{a} \mathrm{Bi} / \mathrm{La}_{0.9} \mathrm{Ba}_{0.1} \mathrm{~F}_{2.9} / \mathrm{CeF}_{3}$ cell after cell preparation (as-milled cathode) (A), after charging to $2.5 \mathrm{~V}(\mathrm{~B})$ and after charging to $3.2 \mathrm{~V}(\mathrm{C})$. For comparison, the intensities of all spectra were normalised to $1 . \mathrm{Bi} 4 \mathrm{f}, \mathrm{F} 1 \mathrm{~s}$ and La $3 \mathrm{~d}$ spectra measured for pure $\mathrm{LaF}_{3}$ and $\mathrm{BiF}_{3}$ materials are given for comparison.

composed of two plateaus at ca. 2.5-2.6 V and 3.1-3.5 V. After charging to $4 \mathrm{~V}$ in the first run, the first discharge was composed of two steps, first a steep decrease of the voltage between 3.7 and $2.3 \mathrm{~V}$ and then a sloping plateau around $2 \mathrm{~V}$. The second charge was also composed of two plateaus, again around $2.5-2.6 \mathrm{~V}$ and between 3.2 and $4 \mathrm{~V}$. Following the reaction process described for the first charge, we assume that the discharge plateau at around $2 \mathrm{~V}$ corresponds to the conversion of $\mathrm{BiF}_{3}$ into $\mathrm{Bi}$. This was confirmed by XRD, which showed that after the first discharge (following charge to $3.2 \mathrm{~V}$ ) the peaks related to $\mathrm{BiF}_{3}$ disappeared almost completely (Fig. $1 \mathrm{~b}$ ), while $\beta-\mathrm{BiF}_{3-2 x} \mathrm{O}_{x}$ was still detected. Therefore, during the following charging, the first plateau at $c a$. 2.5-2.6 $\mathrm{V}$ reflects, like in the first charging process, the conversion of $\mathrm{Bi}$ into $\mathrm{BiF}_{3}$. The second charging plateau at higher voltage (ca. $3.5 \mathrm{~V})$ may be attributed again to the formation of $\mathrm{BiF}_{5}$, as assumed for the third step of the first charge. The conversion of $\mathrm{BiF}_{5}$ into $\mathrm{BiF}_{3}$ when first charging to 4 $\mathrm{V}$ could explain the first discharge step between 3.7 and $2.3 \mathrm{~V}$, which are too high voltage values for the conversion of $\mathrm{BiF}_{3}$ into $\mathrm{Bi}$. The absence of a charge plateau corresponding to $\beta-\mathrm{BiF}_{3-2 x} \mathrm{O}_{x}$ from the second cycle indicated the irreversibility of this phase during discharge.

Thus, during discharge, only $\mathrm{BiF}_{3}$ converts back into $\mathrm{Bi}$, which would explain the lower capacity found during discharge as only one step is reversible. Another interesting feature is the sharpening of the diffraction peaks corresponding to $\mathrm{Bi}$ (Fig. 1b). The melting point of Bi is relatively low $\left(271^{\circ} \mathrm{C}\right)$ and the experiments were performed at $150{ }^{\circ} \mathrm{C}$. It is therefore likely that this elevated temperature favoured the grain growth of the Bi phase in the cathode during cycling. This growth may be detrimental to the overall cycling performance as there is loss of reactive interfaces between the different phases of the cathode 


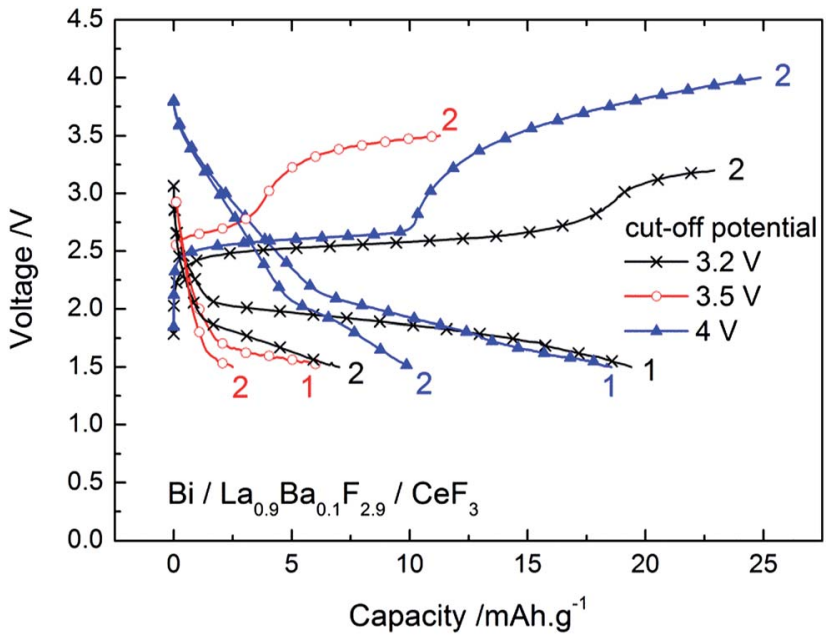

Fig. 3 Voltage-composition profiles for the $\mathrm{Bi} / \mathrm{La}_{0.9} \mathrm{Ba}_{0.1} \mathrm{~F}_{2.9} / \mathrm{CeF}_{3}$ cell in the two first cycles (1st charges are given in Fig. S3, see ESI $\dagger$ ). The charge/discharge curves were obtained at $150{ }^{\circ} \mathrm{C}$ for a current density of ca. $\pm 4 \mathrm{~mA} \mathrm{~g}^{-1}$.

composite. It could also explain the remaining of unreacted $\mathrm{Bi}$, which was observed by XRD and XPS after charging and could correspond to the core of the converted $\mathrm{BiF}_{3}$ particles. Finally, the volume change during fluorination (Table S1†) is also a typical degradation factor for conversion materials, although it is rather limited for $\mathrm{Bi} / \mathrm{BiF}_{3}$.

\section{Fully discharged $\mathrm{CaF}_{2}$ and $\mathrm{MgF}_{2}$ anodes $v s$. a Bi cathode}

Similar experiments were performed using $\mathrm{CaF}_{2}$ and $\mathrm{MgF}_{2}$ as anode materials (Table 1). The theoretical electromotive force (emf) values for $\mathrm{Bi} / \mathrm{BiF}_{3}$ against a $\mathrm{Ca} / \mathrm{CaF}_{2}$ cell is $3.16 \mathrm{~V}$ (Table S1†), so the charge was performed up to $4 \mathrm{~V}$ cut-off potential (Fig. 4a) when using this anode material. The charge capacity was $406 \mathrm{~mA} \mathrm{~h} \mathrm{~g}^{-1}$, again above the theoretical value of $\mathrm{Bi}_{/} / \mathrm{BiF}_{3}$ (Table S1 †). Similar to the observations for $\mathrm{CeF}_{3}$ as the anode precursor material, we observed three regions in the charging curves with higher voltage values, in agreement with the higher electropositive nature of $\mathrm{Ca} / \mathrm{CaF}_{2}$ compared to $\mathrm{Ce} / \mathrm{CeF}_{3}$ (Table $\mathrm{S} 1 \dagger)$. The XRD patterns measured after charging to different potentials (Fig. 5a) confirmed a similar reaction pathway, with first the formation of $\beta-\mathrm{BiF}_{3-2 x} \mathrm{O}_{x}$ (the only phase observed at $3.2 \mathrm{~V}$ ) and then the formation of $\mathrm{BiF}_{3}$ (at 3.5 to $4 \mathrm{~V}$ ) with remaining unreacted $\mathrm{Bi}$. The origin of the third step above $3.6 \mathrm{~V}$ is again not clear from the XRD results but we assume that $\mathrm{BiF}_{3}$ formed during the second step further converts into $\mathrm{BiF}_{5}$, as in the previous system. Unfortunately, after this first charge it was not possible to subsequently discharge the cell. The voltage decreased rapidly when applying the discharge current and capacity values below $5 \mathrm{~mA} \mathrm{~h} \mathrm{~g}{ }^{-1}$ were measured. No further cycling was possible.

The theoretical emf value for a cell $\mathrm{Bi} / \mathrm{BiF}_{3}$ against $\mathrm{Mg} / \mathrm{MgF}_{2}$ is $2.64 \mathrm{~V}$ close to the value obtained for $\mathrm{CeF}_{3}$, therefore the cutoff potential for charging was set to $3.5 \mathrm{~V}$ (Fig. $4 \mathrm{~b}$ ). The charge capacity measured was $406 \mathrm{~mA} \mathrm{~h} \mathrm{~g}^{-1}$ using $\mathrm{MgF}_{2}$ as the starting material for the anode. This value is again higher than the
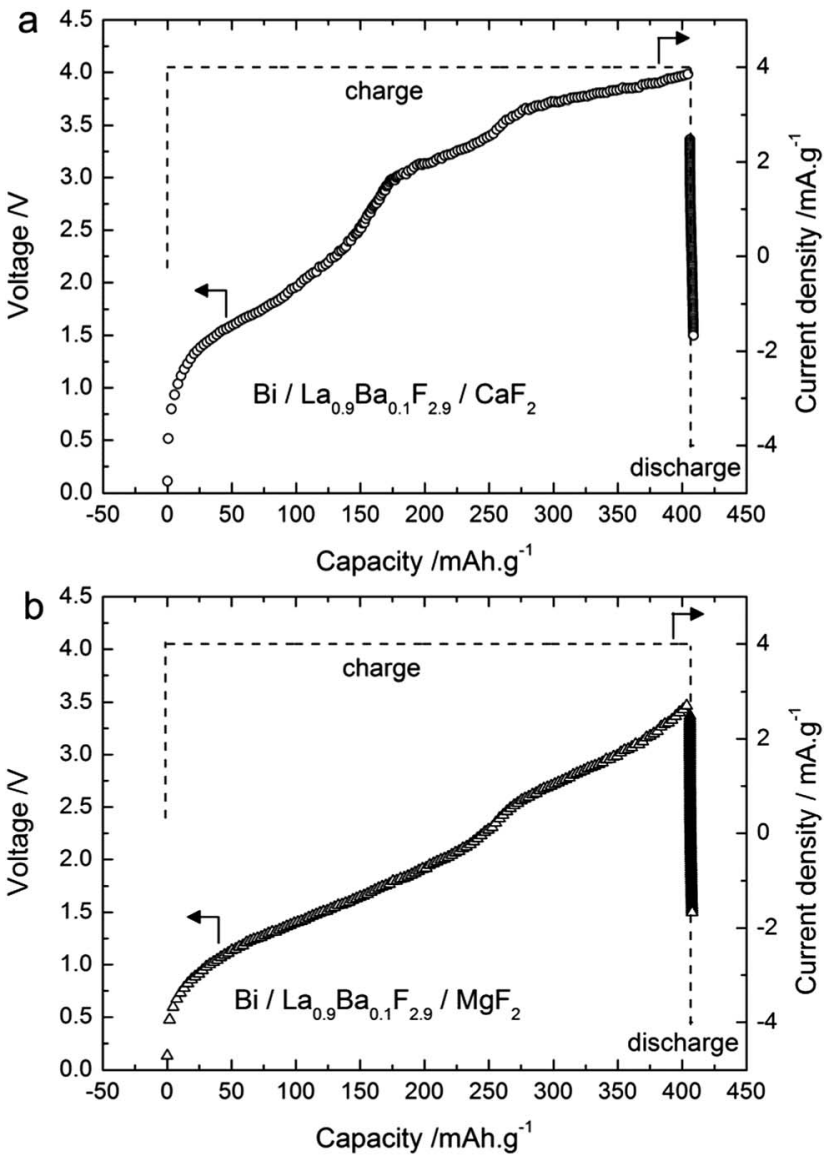

Fig. 4 Voltage-composition profiles for the first cycle of charging and discharging $\left(150{ }^{\circ} \mathrm{C}, \pm 4 \mathrm{~mA} \mathrm{~g}^{-1}\right)$ for the cells (a) Bi/La ${ }_{0.9} \mathrm{Ba}_{0.1} \mathrm{~F}_{2.9} / \mathrm{CaF}_{2}$ and (b) $\mathrm{Bi} / \mathrm{La}_{0.9} \mathrm{Ba}_{0.1} \mathrm{~F}_{2.9} / \mathrm{MgF}_{2}$. Symbols: voltage and dashed lines: current density.

theoretical capacity of $\mathrm{Bi} / \mathrm{BiF}_{3}$, and hence is an indication that a side reaction occurred during charging. We could not observe any voltage plateau but we could observe an inflexion in the voltage profile around $2.5 \mathrm{~V}$ which could indicate the presence of two reaction steps. The XRD pattern measured after charging to $3.5 \mathrm{~V}$ (Fig. $5 \mathrm{~b}$ ) shows the formation of $\beta-\mathrm{BiF}_{3-2 x} \mathrm{O}_{x}$ and $\mathrm{BiF}_{3}$. By analogy with the results observed for the other anode materials, we assume that the first region $(<2.5 \mathrm{~V})$ corresponds to the formation of $\beta-\mathrm{BiF}_{3-2 x} \mathrm{O}_{x}$ and the second one $(>2.5 \mathrm{~V})$ to the formation of $\mathrm{BiF}_{3}$. However, the capacity achieved when reaching $2.5 \mathrm{~V}$ was much higher than with the $\mathrm{CeF}_{3}$ or $\mathrm{CaF}_{2}$ anode, approx. $265 \mathrm{~mA} \mathrm{~h} \mathrm{~g}{ }^{-1}$, which is too high for the conversion of $\mathrm{Bi}_{2} \mathrm{O}_{3}$ to $\beta-\mathrm{BiF}_{3-2 x} \mathrm{O}_{x}$ only (theoretical capacity value is $230 \mathrm{~mA} \mathrm{~h} \mathrm{~g}^{-1}$ for $x=0.5$ ).

In addition, the total capacity was above the theoretical value for $\mathrm{Bi} / \mathrm{BiF}_{3}$. Thus, it is likely that we also had here three steps during charging with the conversion into $\beta-\mathrm{BiF}_{3-2 x} \mathrm{O}_{x}, \mathrm{BiF}_{3}$ and $\mathrm{BiF}_{5}$ but that these steps could not be distinguished clearly during charging due to the lack of plateaus. Also for this anode material, we could detect the presence of unreacted $\mathrm{Bi}$ after charging by XRD. As for the $\mathrm{CaF}_{2}$ anode, the following discharge capacity was really low and no further cycling was possible. 

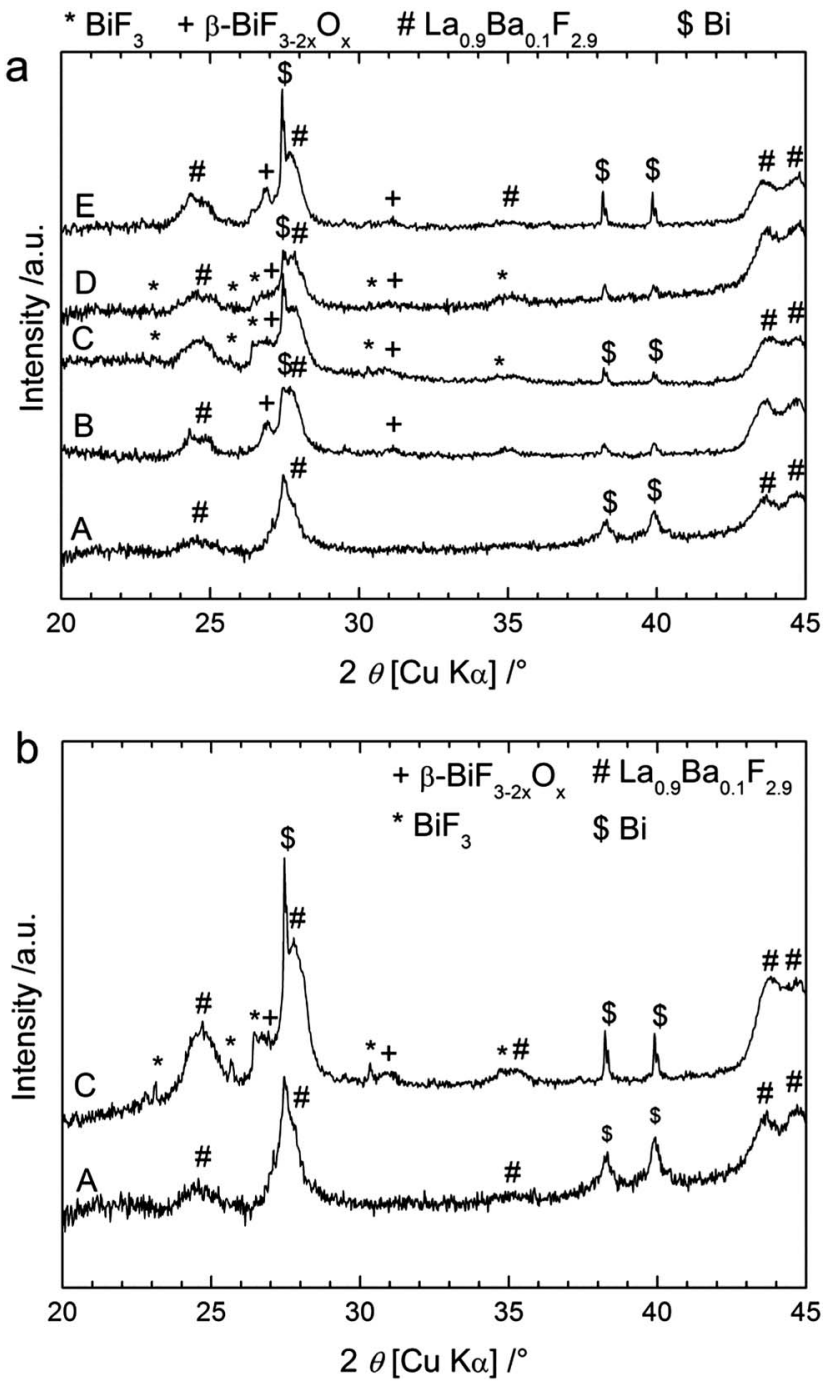

Fig. 5 XRD patterns of the cathode material after cycling a cell with $\mathrm{Bi}$ as the cathode to different stages, using (a) $\mathrm{CaF}_{2}$ as the anode or (b) $\mathrm{MgF}_{2}$ as the anode. The patterns were recorded on the as-milled cathode composite (A), after charging to $3.2 \mathrm{~V}(\mathrm{~B})$, after charging to 3.5 $\mathrm{V}(\mathrm{C})$, after charging to $4 \mathrm{~V}(\mathrm{D})$ and after one cycle (E).

After the first discharge, XRD patterns measured for the cell with $\mathrm{CaF}_{2}$ as the anode (Fig. 5a) show that $\mathrm{BiF}_{3}$ peaks preferentially disappeared compared to $\beta-\mathrm{BiF}_{3-2 x} \mathrm{O}_{x}$ peaks. Nevertheless, we could still clearly see both fluoride phases after discharge explaining the low capacity value measured during discharge and indicating the difficulty in reversing the reaction in this case. At this stage it was not possible to analyse the anode material after charge and discharge because it was used in excess and we assume that reactions only occurred at the interface between the electrolyte and the anode which cannot be probed by XRD or XPS. One explanation for the lack of reversibility compared to the $\mathrm{CeF}_{3}$ anode may be the high reactivity of $\mathrm{Ca}$ or $\mathrm{Mg}$ (e.g. towards $\mathrm{O}_{2}$ ) formed in the anode after charging, which could prevent the reverse conversion of the corresponding fluoride compounds. More investigations are planned to test this hypothesis.

\section{Composite $\mathrm{Mg}+\mathrm{MgF}_{2}$ anodes vs. a Bi cathode}

The first results obtained using fully discharged anodes show the reversible cycling of a FIB using a $\mathrm{CeF}_{3}$ anode. However, the capacities were low, and almost no reversibility was found with $\mathrm{MgF}_{2}$ or $\mathrm{CaF}_{2}$ anodes. Some claims were made that magnesium anodes could be used for a reversible FIB but the operating temperatures were expected to be much higher. ${ }^{27}$ This is likely related to the poor reactivity of $\mathrm{MgF}_{2}$ and also its poor conductivity properties. Baukal ${ }^{28}$ has already described the benefits of mixing the discharge and charge products in the electrode to prepare more reactive interfaces. Following this idea, we prepared a new composite anode by mixing $\mathrm{Mg}$ and $\mathrm{MgF}_{2}$ with the electrolyte and carbon (Table 1). The cycling performances of this $\mathrm{Mg}+\mathrm{MgF}_{2}$ anode can be seen in Fig. 6, using $3.2 \mathrm{~V}$ as the cut-off potential for charging.

The OCV value measured on the as-built cell was $c a .1 .8 \mathrm{~V}$ which was a much higher value than obtained previously, probably due to the presence of $\mathrm{Mg}$, which creates a new redox couple and allows equilibrating thermodynamically. Fig. 6a
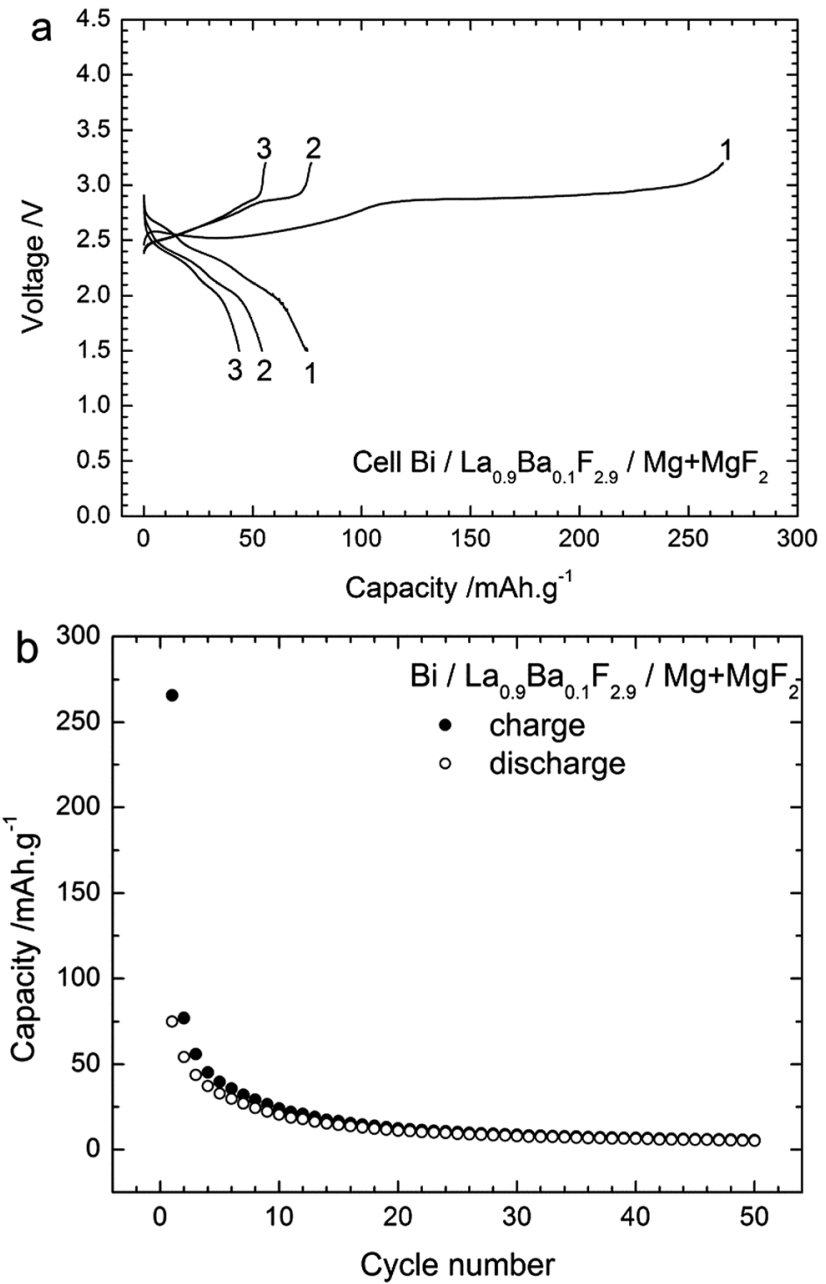

Fig. 6 (a) Voltage-composition profiles for a cell with the Bi cathode vs. $\mathrm{Mg}+\mathrm{MgF}_{2}$ anode in the three first cycles and (b) cycling behaviour of this cell during 50 cycles. The charge/discharge curves were obtained at $150{ }^{\circ} \mathrm{C}$ for a current density of ca. $\pm 4 \mathrm{~mA} \mathrm{~g}^{-1}$. 
shows the voltage profiles measured during the first three cycles. The first charge proceeded as described for the other anode materials with two subsequent steps up to $3.2 \mathrm{~V}$. The first one was a plateau around $2.5 \mathrm{~V}$, much less sloping than found with the other anode materials. The second step was a plateau around $2.9 \mathrm{~V}$. The charge capacity obtained was $266 \mathrm{~mA} \mathrm{~h} \mathrm{~g}{ }^{-1}$; below the theoretical value of the $\mathrm{Bi} / \mathrm{BiF}_{3}$ couple.

During the following discharge, three steps were identified in the voltage profile: a first one with a sloping plateau around $2.7 \mathrm{~V}$, then a second flat plateau around $2.4 \mathrm{~V}$ and finally a third one around $2.1 \mathrm{~V}$. In the next cycles, the first charge plateau became shorter and steeper and the second plateau at $c a .2 .9 \mathrm{~V}$ tended to disappear. In the following discharges, the first step disappeared while the two following ones still occurred but for shorter durations. The cycling behaviour during the 50 first cycles is given in Fig. 6b. After the first charge, the capacities obtained during charge and discharge became rather similar, but decreased rapidly with the cycling number.

XRD was performed on the cathode material after different cycling stages; the measured patterns are shown in Fig. 7. After charging to $2.85 \mathrm{~V}$ (towards the end of the first plateau), only small peaks corresponding to $\beta-\mathrm{BiF}_{3-2 x} \mathrm{O}_{x}$ could be detected in the XRD pattern. After charging to $3.2 \mathrm{~V}$, two new phases appeared in the XRD patterns: $\mathrm{BiF}_{3}$ and $\beta-\mathrm{BiF}_{3-2 x} \mathrm{O}_{x}$, which were also obtained using the other anode materials. The cell parameter for $\beta-\mathrm{BiF}_{3-2 x} \mathrm{O}_{x}$ was $5.83 \AA$ as determined by Rietveld refinement which indicates a higher content of $\mathrm{F}$ (lower $x$ ) in this phase compared to the cell with the $\mathrm{CeF}_{3}$ anode $(a=5.81$ A). The presence of unreacted Bi could be again detected in all XRD patterns as expected from the capacity value, which is below the theoretical value of $\mathrm{Bi} / \mathrm{BiF}_{3}$. Considering the results described above with the $\mathrm{CeF}_{3}$ anode, the charging process using a $\mathrm{Mg}+\mathrm{MgF}_{2}$ anode resembles the formation of $\beta-\mathrm{BiF}_{3-2 x} \mathrm{O}_{x}$ from $\mathrm{Bi}_{2} \mathrm{O}_{3}$ present in the as-milled cathode (plateau around $2.5 \mathrm{~V}$ ) and then the formation of $\mathrm{BiF}_{3}$ from $\mathrm{Bi}$

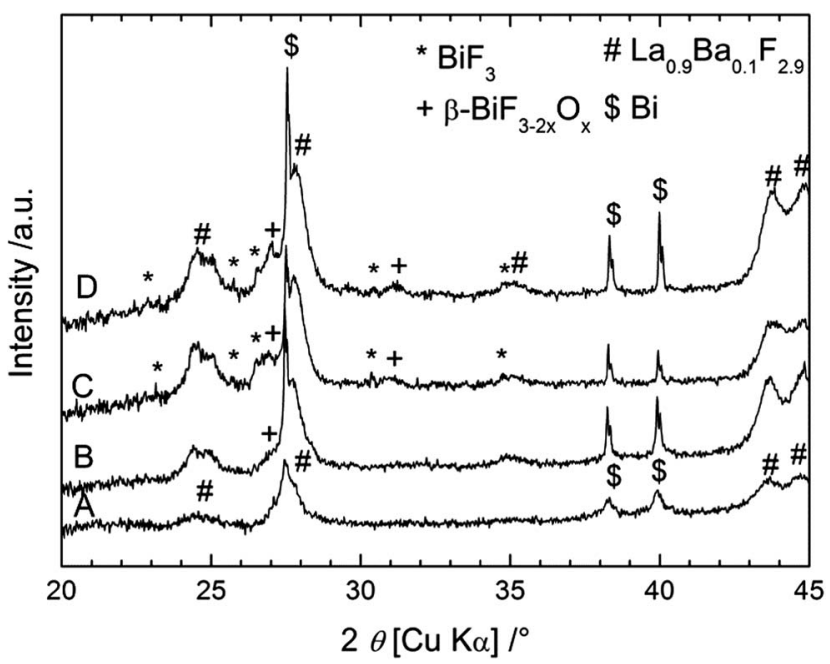

Fig. 7 XRD patterns measured on the back side of the cathode for a $\mathrm{Bi} / \mathrm{La}_{0.9} \mathrm{Ba}_{0.1} \mathrm{~F}_{2.9} / \mathrm{Mg}+\mathrm{MgF}_{2}$ cell before charging (A), after charging to $2.85 \mathrm{~V}(\mathrm{~B})$, after charging to $3.2 \mathrm{~V}(\mathrm{C})$ and after discharge (D). (plateau around $2.9 \mathrm{~V}$ ). When stopping the charging at $3.2 \mathrm{~V}$, we could not observe the third step described in the first section with the formation of $\mathrm{BiF}_{5}$, but it was present when charging to $4 \mathrm{~V}$ (not shown). The plateau voltages upon charging were slightly higher than those obtained previously which may have several origins, leading to higher kinetic barriers, including higher resistance or lower conductivity. Upon cycling, we observed a sharpening of the diffraction peaks for $\mathrm{Bi}$, which could again be related to grain growth. After the discharge, the two fluoride phases could still be detected, but an accurate quantification was not possible using only the XRD measurements.

Additionally, we analysed the surface of the back side of the cathode by XPS (Fig. 8). On the outer surface (Fig. 8a), we could
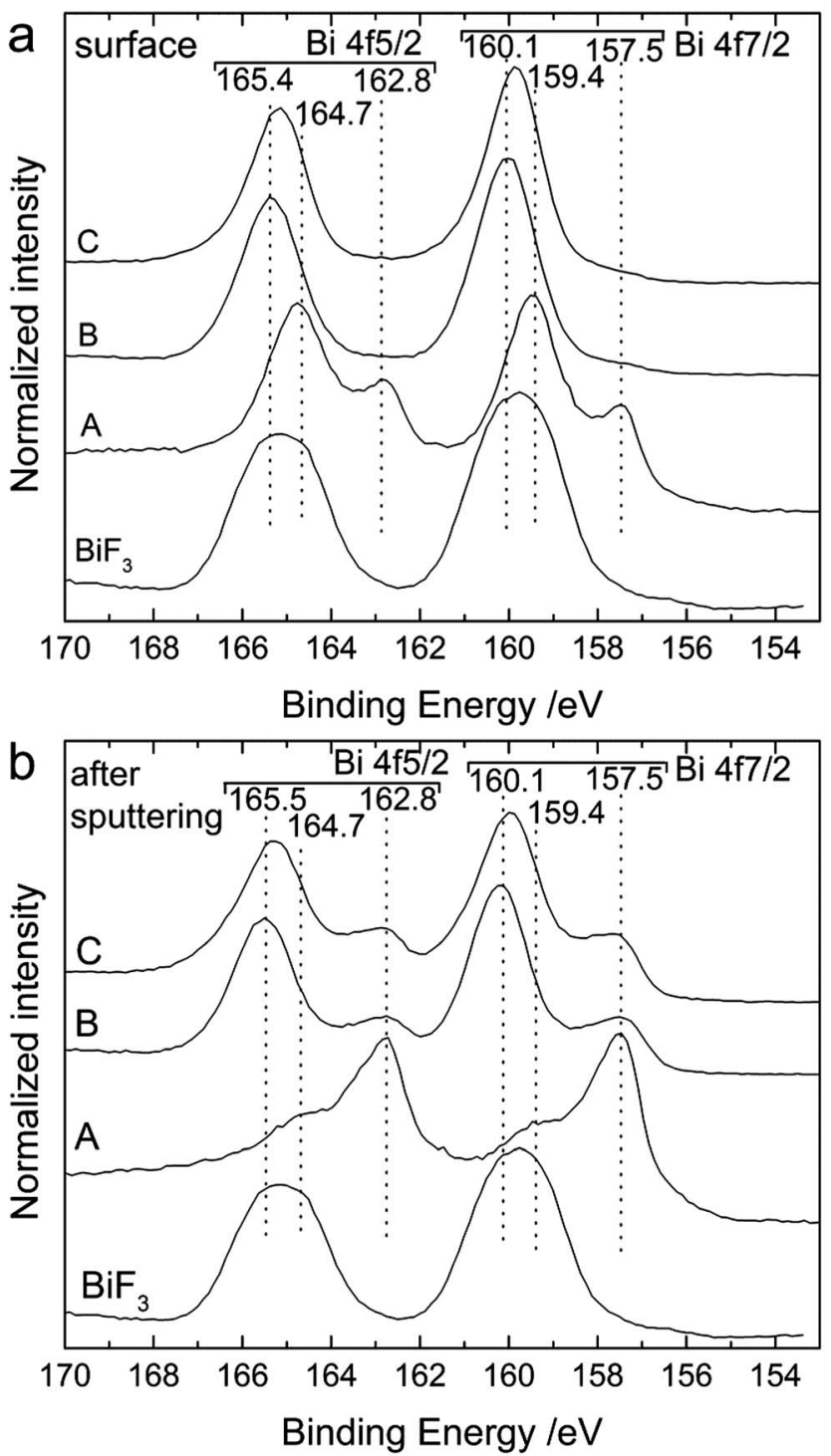

Fig. 8 XP spectra of the Bi $4 \mathrm{f}$ region measured at (a) the surface and (b) after sputtering the outer layer of the back side of the cathode for a Bi/ $\mathrm{La}_{0.9} \mathrm{Ba}_{0.1} \mathrm{~F}_{2.9} / \mathrm{Mg}+\mathrm{MgF}_{2}$ cell after cell preparation (as-milled cathode) (A), after charging to $3.2 \mathrm{~V}$ (B) and after discharge (C). For comparison, the intensities of all spectra were normalised to 1. 
clearly see the shift of the Bi $4 \mathrm{f}$ peaks towards higher binding energies after charging. As discussed above, before cycling the surface was composed of metallic Bi (157.5 and $162.8 \mathrm{eV}$ ) and $\mathrm{Bi}_{2} \mathrm{O}_{3}$ (159.4 and $\left.164.7 \mathrm{eV}\right)$. In the charged state, only one doublet was present at 160.0 and $165.4 \mathrm{eV}$, which is attributed to a mixture of $\mathrm{BiF}_{3}$ and $\beta-\mathrm{BiF}_{3-2 x} \mathrm{O}_{x}$ as already described for Fig. 2 . The same doublet was still present after discharge. Below the top surface layer (after sputtering), two doublets were present after charging corresponding to $\mathrm{Bi}(157.5$ and $162.7 \mathrm{eV})$ and unreacted $\mathrm{BiF}_{3}$ (160.1 and $165.5 \mathrm{eV}$ ), respectively. These two doublets were still present after discharge but the intensity ratio $\mathrm{BiF}_{3}$ : Bi slightly decreased indicating an increased amount of $\mathrm{Bi}$. The absence of $\mathrm{Bi}$ at the surface after discharge and the limited increase of the $\mathrm{BiF}_{3}$ : $\mathrm{Bi}$ ratio below the top layer indicate that the conversion of $\mathrm{BiF}_{3}$ into $\mathrm{Bi}$ during discharge was mainly taking place at the interface of the electrode to the electrolyte, while the top layers were not fully converted. This could at least partly explain the low discharge capacity. Surprisingly, the first charging encompassed the entire cathode thickness and the charge capacity reached $70 \%$ of the theoretical value.

Summarizing the different results, the reaction process for a $\mathrm{Bi} / \mathrm{La}_{0.9} \mathrm{Ba}_{0.1} \mathrm{~F}_{2.9} / \mathrm{Mg}+\mathrm{MgF}_{2}$ cell during charging is composed of two steps corresponding to two voltage plateaus: the formation of $\beta-\mathrm{BiF}_{3-2 x} \mathrm{O}_{x}$ from $\mathrm{Bi}_{2} \mathrm{O}_{3}$ at ca. $2.5 \mathrm{~V}$ and the formation of $\mathrm{BiF}_{3}$ from $\mathrm{Bi}$ at $c a$. 2.9 $\mathrm{V}$. During discharge, a plateau at $c a .2 .7 \mathrm{~V}$ appears only during the first cycle and corresponds either to a side reaction (but no $\mathrm{BiF}_{5}$ was formed during charge) or to kinetic effects that could not be clearly identified here. Then, a second plateau at $2.4 \mathrm{~V}$ can be attributed to the conversion of $\mathrm{BiF}_{3}$ into $\mathrm{Bi}$ as described previously for the $\mathrm{CeF}_{3}$ anode and finally the last plateau at $2.1 \mathrm{~V}$ may correspond to the release of $\mathrm{F}$ from $\beta-\mathrm{BiF}_{3-2 x} \mathrm{O}_{x}$ rather than the reverse conversion into $\mathrm{Bi}_{2} \mathrm{O}_{3}$ (not detected by XRD or XPS). This last step would be in agreement with the slight decrease of the cell parameter of $\beta-\mathrm{BiF}_{3-2 x} \mathrm{O}_{x}$ from $5.83 \AA$ after charge to $5.82 \AA$ after discharge, determined by Rietveld refinement.

Overall, the better cycling performance obtained starting from a half-discharged composite $\mathrm{Mg}+\mathrm{MgF}_{2}$ anode compared to $\mathrm{CeF}_{3}$ is mainly related to the better discharge behaviour. In this case, it is possible to reverse at least partially the two steps of charging from $\mathrm{Bi}_{2} \mathrm{O}_{3}$ to $\beta-\mathrm{BiF}_{3-2 x} \mathrm{O}_{x}$ and from $\mathrm{Bi}$ to $\mathrm{BiF}_{3}$ whereas only the conversion of $\mathrm{BiF}_{3}$ into $\mathrm{Bi}$ was possible with $\mathrm{CeF}_{3}$. This may be related to the higher content of $\mathrm{F}$ (lower $x$ ) in the $\beta-\mathrm{BiF}_{3-2 x} \mathrm{O}_{x}$ when charging against $\mathrm{Mg}+\mathrm{MgF}_{2}$, which implies a higher quantity of $\mathrm{F}$ available for discharge. In addition, the unchanged XP spectra measured on the outer surface of the cathode after charging and discharging indicate that the discharge reaction occurs mainly at the cathode/electrolyte interface and does not reach the full cathode layer. This incomplete reaction is in agreement with the lower discharge capacities compared to the charge capacities, indicating that the discharge process suffers from more or higher kinetic barriers than charging. Finally, compared to the performance using $\mathrm{MgF}_{2}$ alone as the anode, the improvement is striking as no discharge was obtained in the latter case. The presence of $\mathrm{Mg}$ in the starting anode composite appears to be a key component although its role at this point is unclear. One possibility is the availability of $\mathrm{Mg}$ from the starting anode composite during discharge, whereas the metallic $\mathrm{Mg}$ formed during charging in the $\mathrm{MgF}_{2}$ anode may not be accessible for discharge. This could be due to oxidation (formation of a $\mathrm{MgO}$ inert layer at the surface) or due to contact losses because of volume change during charge $\left(+40 \%\right.$ from $\mathrm{Mg}$ to $\mathrm{MgF}_{2}$, Table $\left.\mathrm{S} 1 \dagger\right)$. In addition, the presence of $\mathrm{Mg}$ could improve the conductivity (ionic and/or electronic), or the interface contacts between the different reacting phases.

\section{Composite $\mathrm{Mg}+\mathrm{MgF}_{2}$ anodes vs. a Cu cathode}

Additionally, the performance of another cathode material, in this case $\mathrm{Cu}$, was studied using the composite $\mathrm{Mg}+\mathrm{MgF}_{2}$ as the anode. $\mathrm{Cu}$ as the cathode material has some advantages compared to $\mathrm{Bi}$ as the theoretical capacity of the $\mathrm{Cu} / \mathrm{CuF}_{2}$ couple is higher ( $843 \mathrm{~mA} \mathrm{~h} \mathrm{~g}^{-1}$ referring to the mass of $\mathrm{Cu}$ ) and the emf is also higher $\left(2.98 \mathrm{~V}\right.$ vs. $\mathrm{Mg} / \mathrm{MgF}_{2}$ ) compared to the $\mathrm{Bi} / \mathrm{BiF}_{3}$
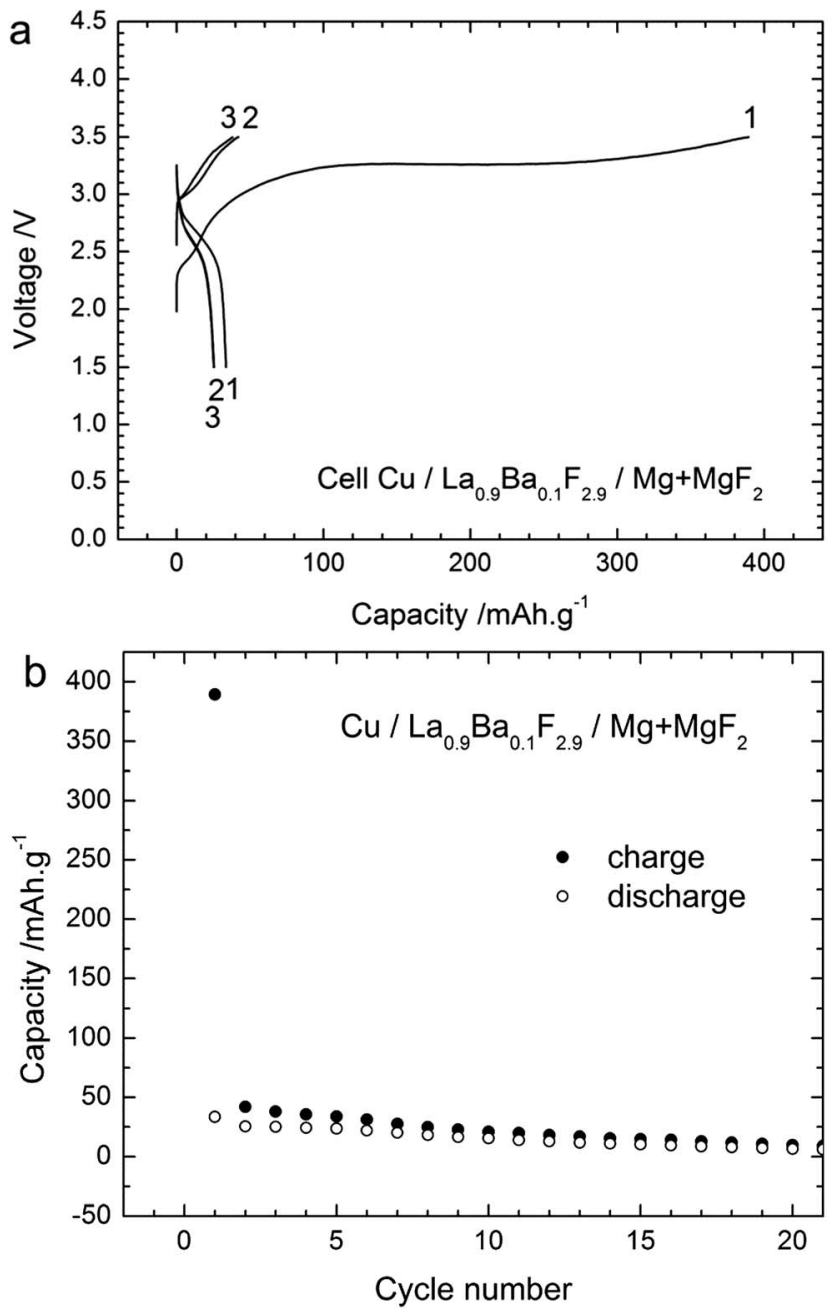

Fig. 9 (a) Voltage-composition profiles for the same cell with the $\mathrm{Cu}$ cathode vs. the $\mathrm{Mg}+\mathrm{MgF}_{2}$ anode in the three first cycles and (b) Cycling behaviour of this cell during 20 cycles. The charge/discharge curves were obtained at $150{ }^{\circ} \mathrm{C}$ for a current density of ca. $\pm 4 \mathrm{~mA} \mathrm{~g}^{-1}$. 
couple (Table S1†). Fig. 9 gives the voltage profiles during cycling and the evolution of the capacity upon cycling for a $\mathrm{Cu} /$ $\mathrm{La}_{0.9} \mathrm{Ba}_{0.1} \mathrm{~F}_{2.9} / \mathrm{Mg}+\mathrm{MgF}_{2}$ cell. The open circuit voltage measured after assembling the cell was close to $1.8 \mathrm{~V}$, similar to what was observed with the $\mathrm{Bi}$ cathode. The first charge was mainly composed of a single voltage plateau at around $3.25 \mathrm{~V}$ in agreement with the emf of the $\mathrm{Cu} / \mathrm{CuF}_{2}$ couple $v s . \mathrm{Mg} / \mathrm{MgF}_{2}$. The first charge capacity was $390 \mathrm{~mA} \mathrm{~h}^{-1}$ lower than the theoretical capacity indicating an incomplete reaction. The capacity faded rapidly during the following cycles, the first discharge capacity was only $33 \mathrm{~mA} \mathrm{~h} \mathrm{~g}^{-1}$ and it was below $20 \mathrm{~mA} \mathrm{~h} \mathrm{~g}^{-1}$ after the 10th cycle. Both charging and discharging were only composed of a single voltage plateau corresponding to a single reaction, in contrast to what was observed for the Bi cathode. Note that the preparation of cells using a $\mathrm{Cu}$ cathode and a $\mathrm{CeF}_{3}$ or $\mathrm{CaF}_{2}$ anode failed. No charging was possible and only the formation of $\mathrm{Cu}_{2} \mathrm{O}$ could be detected after applying charge currents to the cells (not shown) with a voltage of around 1.8-2 V. Using $\mathrm{Mg}+$ $\mathrm{MgF}_{2}$ as the anode, the measured voltage was superior to this value already from the OCV which could probably allow avoiding this side reaction. The origin of oxygen is not clear at this point, but it could be attributed to the carbon added in the composite which could still contain minor amounts of water after drying.

Again, XRD measurements (Fig. 10) were performed to understand the reactions during charging and discharging. Before charge (after milling), only two phases were observed, namely the active material $\mathrm{Cu}$ and the electrolyte $\mathrm{La}_{0.9} \mathrm{Ba}_{0.1} \mathrm{~F}_{2.9}$, whose reflections overlapped. Note that it was not possible to detect the presence of $\mathrm{Cu}_{2} \mathrm{O}$ which was present in the asreceived $\mathrm{Cu}$ powder (see ESI, Fig. $\mathrm{S} 2 \dagger$ ). As for the Bi cathode, the diffraction peaks were broadened, indicative of a small crystallite size: $17 \mathrm{~nm}$ for $\mathrm{La}_{0.9} \mathrm{Ba}_{0.1} \mathrm{~F}_{2.9}$ and $13 \mathrm{~nm}$ for $\mathrm{Cu}$. After

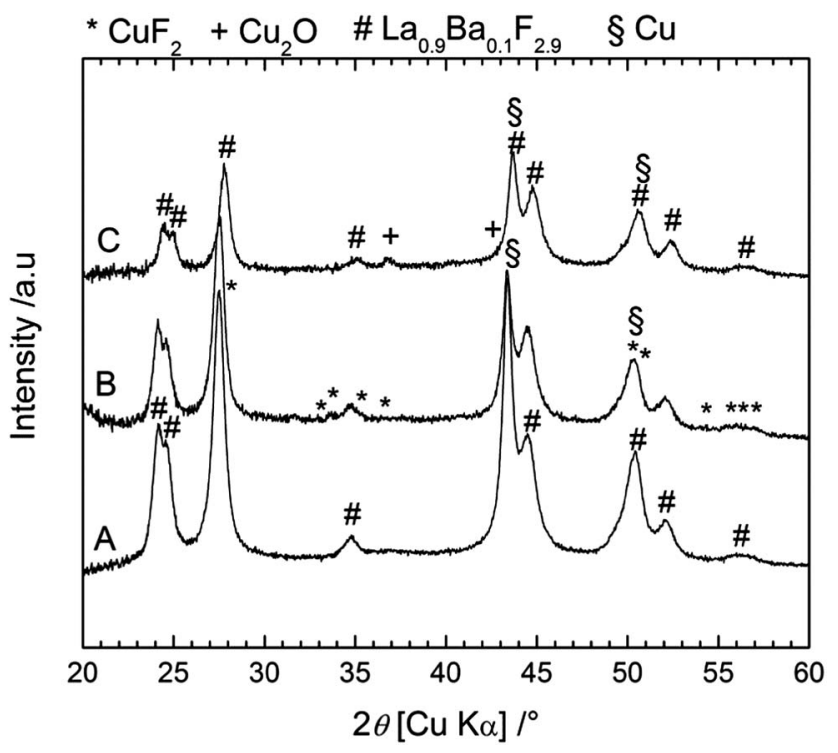

Fig. $10 \mathrm{XRD}$ patterns measured on the back side of the cathode for $a$ $\mathrm{Cu} / \mathrm{La}_{0.9} \mathrm{Ba}_{0.1} \mathrm{~F}_{2.9} / \mathrm{Mg}+\mathrm{MgF}_{2}$ cell before charging $(\mathrm{A})$, after charging to $3.5 \mathrm{~V}(\mathrm{~B})$ and after discharge (C). charging, some weak peaks appeared which correspond to $\mathrm{CuF}_{2}$, and confirm the charge reaction. The diffraction peaks corresponding to $\mathrm{Cu}$ overlap with those of the electrolyte but from the ratio of the reflections at $43.3^{\circ}\left(\mathrm{Cu}+\mathrm{La}_{0.9} \mathrm{Ba}_{0.1} \mathrm{~F}_{2.9}\right)$ and at $44.4^{\circ}\left(\mathrm{La}_{0.9} \mathrm{Ba}_{0.1} \mathrm{~F}_{2.9}\right.$ only), it can be concluded that the quantity of pure $\mathrm{Cu}$ decreased in the cathode. As expected from the charge capacity value, the reaction from $\mathrm{Cu}$ to $\mathrm{CuF}_{2}$ was not complete. After discharge, the peaks corresponding to $\mathrm{CuF}_{2}$ disappeared, but peaks corresponding to $\mathrm{Cu}_{2} \mathrm{O}$ could be observed. These results show that the charge reaction from $\mathrm{Cu}$ to $\mathrm{CuF}_{2}$ was partly reversible; the formation of $\mathrm{Cu}_{2} \mathrm{O}$ after discharge can explain the large decrease of the capacity in the following cycles. In contrast with the Bi cathode, there seems to be only a weak growth of the Cu grains (crystallite size of $40 \mathrm{~nm}$ calculated after one cycle), due to its higher melting point (1083 $\left.{ }^{\circ} \mathrm{C}\right)$. This limited grain growth should not hamper further reactions as sufficient reactive interfaces should still be available in the $\mathrm{Cu}$ cathode during cycling. However, the transformation from $\mathrm{Cu}$ to $\mathrm{CuF}_{2}$ involves a very large volume change (ca. $192 \%$, Table $\mathrm{S} 1 \dagger$ ) that likely leads to contact losses in the cathode material. These losses could also explain the rapid degradation of the cell performance upon cycling.

Additional XPS experiments (Fig. 11) were performed on the cathode side of cycled pellets to confirm the reaction mechanism. The spectra measured for the $\mathrm{Cu} 2 \mathrm{p}$ energy region confirmed the formation of $\mathrm{CuF}_{2}$ after charging. For the asmilled cathode material (at the surface and after sputtering), only one doublet was obtained at $932.6 \mathrm{eV}$ for the $\mathrm{Cu} 2 \mathrm{p} 3 / 2$ level and at $952.5 \mathrm{eV}$ for the $\mathrm{Cu} 2 \mathrm{p} 1 / 2$ level (Fig. 11a and b) which correspond to the presence of metallic $\mathrm{Cu} .{ }^{29}$ It is important to note, however, that the peak doublet corresponding to $\mathrm{Cu}_{2} \mathrm{O}$ has been reported for exactly the same binding energy value as for metallic $\mathrm{Cu}^{29}$ so the presence of such an oxide cannot be ruled out here. $\mathrm{Cu}_{2} \mathrm{O}$ was present in the starting $\mathrm{Cu}$ powder (see ESI, Fig. S2 $\uparrow$ ), indeed, although it cannot be detected by XRD in the as-prepared cathode material. After charging the cell to $3.5 \mathrm{~V}$, an additional peak doublet at 936.0 and $956.5 \mathrm{eV}$ could be clearly seen which represents the main lines of $\mathrm{CuF}_{2}$, while the peaks at 943.7 and $963.2 \mathrm{eV}$ are the satellite features of $\mathrm{CuF}_{2} \cdot{ }^{30}$ As for the $\mathrm{Bi}$ cathode, it is interesting to note that the presence of $\mathrm{CuF}_{2}$ could be detected through the complete pellet as it was seen at the surface layer of the cathode back side. After charging, there were still pronounced peaks corresponding to metallic $\mathrm{Cu}$ in agreement with the incomplete transformation of $\mathrm{Cu}$ into $\mathrm{CuF}_{2}$ also observed by XRD and the charge capacity which was measured to be below the theoretical value.

After discharge, the presence of $\mathrm{CuF}_{2}$ could still be detected at the surface, whereas it almost completely disappeared after sputtering. The presence of remaining $\mathrm{CuF}_{2}$ at the surface after discharge indicates that the reversible conversion of $\mathrm{CuF}_{2}$ into $\mathrm{Cu}$ during discharge had mostly taken place close to the interface between the cathode and the electrolyte. This can partly explain the lower discharge capacity measured during discharge. Again, the main peak doublet at 932.6 and $952.5 \mathrm{eV}$ is likely a combination of the contributions from unreacted metallic $\mathrm{Cu}$ and $\mathrm{Cu}_{2} \mathrm{O}$, which were detected by XRD. The presence of $\mathrm{Cu}_{2} \mathrm{O}$ could be confirmed by the analysis of the $\mathrm{O} 1 \mathrm{~s}$ 

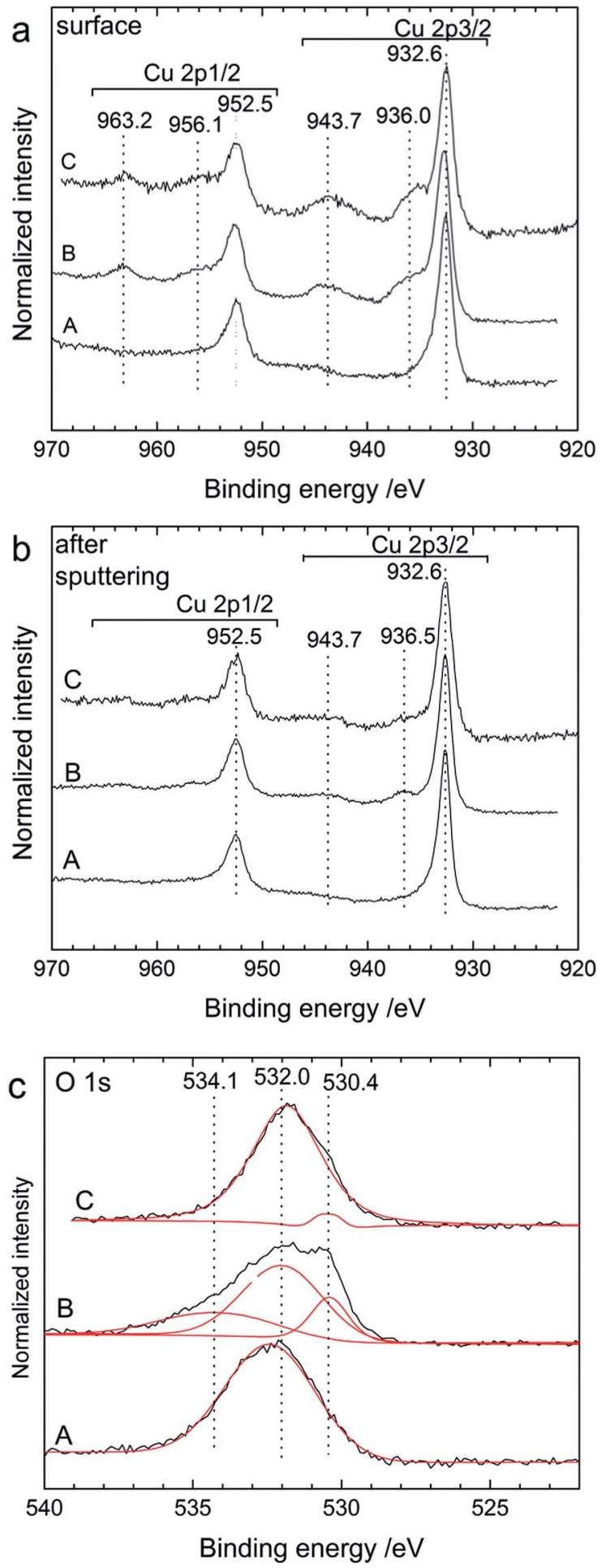

Fig. $11 X P$ spectra for the $\mathrm{Cu} 2 \mathrm{p}$ region measured at (a) the surface and (b) after sputtering the outer layer of the back side of the cathode and (c) XP spectra of the $O 1$ s region (black: measurements and red: fit) after sputtering for a $\mathrm{Cu} / \mathrm{La}_{0.9} \mathrm{Ba}_{0.1} \mathrm{~F}_{2.9} / \mathrm{Mg}+\mathrm{MgF}_{2}$ cell after cell preparation (asmilled cathode) (A), after charging to $3.5 \mathrm{~V}$ (B) and after discharge (C). For comparison, the intensities of all spectra were normalised to 1.

energy region. At the surface, the $\mathrm{O} 1 \mathrm{~s}$ spectra were all composed of a large peak centred around $532 \mathrm{eV}$ (not shown), which is probably related to the presence of various oxides from the different electrode components (e.g. native oxide layers). After sputtering the outer layer, the spectra measured after different cycling stages showed differences (Fig. 11c). A broad peak at $532 \mathrm{eV}$ remained as the main contribution. The total amount of oxygen in the surface region was, however, drastically reduced after sputtering. After charging, the $\mathrm{O} 1 \mathrm{~s}$ peak could be fitted with two more contributions at 534.1 and $530.4 \mathrm{eV}$. The contribution at $534.1 \mathrm{eV}$ could not be identified at this stage but such high energy values usually correspond to adsorbed oxide or hydroxide compounds. ${ }^{31}$ The contribution at $530.4 \mathrm{eV}$ could be ascribed to the presence of $\mathrm{Cu}_{2} \mathrm{O},{ }^{29}$ which was still present after discharge, indicating that this compound was actually not formed during discharge as observed by XRD but already during charge. Note that the presence of $\mathrm{Cu}_{2} \mathrm{O}$ cannot be clearly resolved in the initial as-milled $\mathrm{Cu}$ cathode, although its contribution may be hidden in the broad main peak. Hence, the ball milling process largely removed the oxide layer present in the initial $\mathrm{Cu}$ powder.

To summarise the different results, we show that it is possible to reversibly charge and discharge a Cu cathode using a half-discharged $\mathrm{Mg}+\mathrm{MgF}_{2}$ composite electrode as the starting anode. During charging, a single reaction occurs leading to the formation of $\mathrm{CuF}_{2}$ and during discharge this reaction is partly reversible. However, such a cell shows a rapid decrease of the capacity during cycling which could be explained by the formation of $\mathrm{Cu}_{2} \mathrm{O}$ as the side product and probably from contact losses due to the volume expansion during the formation of $\mathrm{CuF}_{2}$. Therefore, it is necessary to improve the electrode architecture to compensate/solve these issues and enhance the cycling performance of such a FIB.

\section{Conclusions}

Batteries based on a fluoride shuttle have very high theoretical energy densities and could be attractive as alternatives to Li-ion batteries in certain applications. So far, only a few studies have been published reporting on reversible charge/discharge processes in such new systems. In this work, we demonstrate for the first time the reversible charge and discharge of a FIB starting from electrodes in the discharged state. After the first charging, where the cathode was almost fully reacted, cycling was possible for several cycles, however, with a rapid decrease of the capacities upon cycling. The best cycling performance was obtained using a half discharged anode made of a composite of $\mathrm{MgF}_{2}, \mathrm{Mg}$, electrolyte and carbon. The temperature used here, $150{ }^{\circ} \mathrm{C}$, was much lower than the values given previously for operating a $\mathrm{Mg}$ anode. These results are quite encouraging as the electrolyte and electrode preparations were not yet optimised. Several factors may explain the rapid degradation of the electrode properties and the decrease of capacity. They are mainly related to an incomplete discharge process and probably due to a loss of the initial morphology of the nanocomposite consisting of an intimate mixture of all reactants that facilitates the reactions. In the case of the Bi cathode, this is linked to the grain growth in the $\mathrm{Bi}$ phase that limited the reaction rate, not all of the active material was reached. In addition, for this cathode material, the formation of the $\beta-\mathrm{BiF}_{3-2 x} \mathrm{O}_{x}$ phase was 
observed upon charging, but could not be totally discharged afterwards. For the $\mathrm{Cu}$ cathode, it was possible to keep the nanostructure of $\mathrm{Cu}$ but there was likely a large fraction of active material that could not react because of contact loss, due to large volume expansion, and the formation of $\mathrm{Cu}_{2} \mathrm{O}$. To further improve the properties of the cathode materials, a more sophisticated preparation of the electrode structure is necessary, which allows us to maintain the original nanostructure for preserving good contacts between the active phases. At this point, the structure of the anode material could not be investigated in detail and more experiments are in progress to understand the reactions occurring at the anode and to improve the overall performances. Finally, this work opens new routes for the preparation of electrode materials not only using a solid electrolyte but also for FIBs working with a liquid electrolyte. In the latter case, the ionic conductivity of the electrolyte is expected to be better as well as the contacts between the electrodes and electrolyte. Nevertheless, issues concerning the reactivity of the different phases and/or interfaces within the electrodes, to ensure efficient conversion reactions between the metal and the metal fluoride, remain.

\section{Acknowledgements}

Financial support by the State of Baden-Württemberg, Project house e-drive (\#PHed.L.0208.01) is gratefully acknowledged. We also would like to thank N. Schwarzburger for her assistance in the preparation and transfer of the XPS samples.

\section{Notes and references}

1 X. Zhao, S. Ren, M. Bruns and M. Fichtner, J. Power Sources, 2013, 245, 706-711.

2 P. Hartmann, C. L. Bender, M. Vračar, A. K. Dürr, A. Garsuch, J. Janek and P. Adelhelm, Nat. Mater., 2013, 12, 228-232.

3 H. D. Yoo, I. Shterenberg, Y. Gofer, G. Gershinsky, N. Pour and D. Aurbach, Energy Environ. Sci., 2013, 6, 2265-2279.

4 C.-X. Zu and H. Li, Energy Environ. Sci., 2011, 4, 2614.

5 J. Cabana, L. Monconduit, D. Larcher and M. R. Palacín, Adv. Mater., 2010, 22, E170-E192.

6 M. Anji Reddy and M. Fichtner, J. Mater. Chem., 2011, 21, 17059-17062.

7 C. Rongeat, M. Anji Reddy, R. Witter and M. Fichtner, J. Phys. Chem. C, 2013, 117, 4943-4950.

8 A. Düvel, J. Bednarcik, V. Sepelák and P. Heitjans, J. Phys. Chem. C, 2014, 118, 7117-7129.
9 W. Puin, S. Rodewald, R. Ramlau, P. Heitjans and J. Maier, Solid State Ionics, 2000, 131, 159-164.

10 B. Ruprecht, M. Wilkening, A. Feldhoff, S. Steuernagel and P. Heitjans, Phys. Chem. Chem. Phys., 2009, 11, 3071-3081.

11 N. Sata, K. Eberman, K. Eberl and J. Maier, Nature, 2000, 408, 946-949.

12 C. Rongeat, M. Anji Reddy, R. Witter and M. Fichtner, ACS Appl. Mater. Interfaces, 2014, 6, 2103-2110.

13 F. Gschwind, Z. Zhao-Karger and M. Fichtner, J. Mater. Chem. A, 2014, 2, 1214-1218.

14 J. H. Kennedy and J. C. Hunter, J. Electrochem. Soc., 1976, 123, 10-14.

15 J. Schoonman, J. Electrochem. Soc., 1976, 123, 1772-1775.

16 J. Schoonman and A. Wolfert, J. Electrochem. Soc., 1981, 128, 1522-1523.

17 J. Schoonman and A. Wolfert, Solid State Ionics, 1981, 3-4, 373-379.

18 A. A. Potanin, Russ. Chem. J., 2001, 45, 61-66.

19 Y. Danto, G. Poujade, J. D. Pistré, C. Lucat and J. Salardenne, Thin Solid Films, 1978, 55, 347-354.

20 L. Lutterotti, http://www.ing.unitn.it/ maud/, 2011.

21 A. Morell, B. Tanguy and J. Portier, Bull. Soc. Chim. Fr., 1971, 7, 2502-2504.

22 W. E. Morgan, W. J. Stec and J. R. Van Wazer, Inorg. Chem., 1972, 12, 953-955.

23 M. Wang, Q.-L. Huang, X.-T. Chen and X.-Z. You, Mater. Lett., 2007, 61, 4666-4669.

24 D. Barreca, A. Gasparotto, C. Maragno, E. Tondello, E. Bontempi, L. E. Depero and C. Sada, Chem. Vap. Deposition, 2005, 11, 426-432.

25 K. H. Park and S. J. Oh, Phys. Rev. B: Condens. Matter Mater. Phys., 1993, 48, 14833-14842.

26 P. Burroughs, A. Hamnett, A. F. Orchard and G. Thornton, J. Chem. Soc., Dalton Trans., 1976, 17, 1686-1698.

27 W. Baukal, R. Knodler and W. Kuhn, Chem. Ing. Tech., 1978, 50, 245-249.

28 W. Baukal, Electrochim. Acta, 1974, 19, 687-694.

29 J. Ghijsen, L. H. Tjeng, J. van Elp, H. Eskes, J. Westerink, G. A. Sawatzky and M. T. Czyzyk, Phys. Rev. B: Condens. Matter Mater. Phys., 1988, 38, 11322-11330.

30 G. van der Laan, C. Westra, C. Haas and G. A. Sawatzky, Phys. Rev. B: Condens. Matter Mater. Phys., 1981, 23, 4369-4380.

31 K. Koshmak, A. Banshchikov, T. Vergentev, M. Montecchi, D. Ceolin, J. P. Rueff, N. S. Sokolov and L. Pasquali, J. Phys. Chem. C, 2014, 118, 10122-10130. 